\title{
Bir Pazarlama İletişimi Aracı Olarak Talebe Yönelik Video (Video On Demand) Platformlarının Twitter Kullanımı: Netflix Türkiye'nin Covid-19 Öncesi ve Sonrası Kullanımları Özelinde Bir İnceleme
}

\author{
Dilek Melike Uluçay (Dr. Öğr. Üyesi) \\ Yaşar Üniversitesi Illetişim Fakültesi \\ melike.taner@yasar.edu.tr
}

Güven Zararsız (Yarı zamanlı Öğr. Gör.)

iD Yaşar Üniversitesi Illetişim Fakültesi

guven.zararsiz@yasar.edu.tr

Umut Can Aytekin (Yüksek Lisans Öğrencisi)

Yaşar Üniversitesi Iletișim Fakültesi

umutcanaytekin@gmail.com

Başvuru Tarihi: 02.03.2021

Yayına Kabul Tarihi: 24.05.2021

Yayınlanma Tarihi: 30.07.2021

https://doi.org/10.17680/erciyesiletisim.890011

\section{Öz}

Medya teknolojilerinin gelişiminin belirgin gözlendiği alanlardan biri tüketicinin eğlence amaçlı olarak tükettiği araçlar, platformlar ve hizmetlerdir. Özellikle abonelik usulü hizmet veren "talebe yönelik" (video on demand-VOD) platformlar, izleyicilerin 7/24 mobil teknolojiler üzerinden erişiminin bulunduğu zengin içerik tüketimine olanak veren platformlardır. Netflix, dünyada yaygın olarak kullanılan bir VOD platformudur. Firma, sosyal medyayı ana pazarlama iletişiminin bir parçası olarak kullanmaktadır. Bu bağlamda Twitter, Netflix'in en sık kullandığı mecradır. Bu çalışma, Netflix Türkiye'nin Twitter'ı bir pazarlama iletişimi aracı olarak nasıl kullandığını ortaya çıkarmayı amaçlamaktadır. Aynı zamanda bu çalışma, COVID-19 sebebi ile tüketicilerin evde daha çok vakit geçirdiği ve buna bağlı olarak ekran karşısında kalma sürelerinin arttığı bu dönemde, firmanın Twitter kullanım stratejilerinde değişiklik yapıp yapmadığını sorgulamaktadır. Bu kapsamda, Netflix Türkiye'nin Twitter hesabı üzerinde yaptığı toplam 228 paylaşım üzerinde nicel içerik analizi yapılmıştır. Çalışmanın sonuçlarına göre Netflix, her iki dönemde de ağırlıklı olarak Twitter paylaşımlarını içerik tanıtımı yapmak için kullanmıştır. Bununla birlikte firmanın en çok kullandığı eklenti, her iki dönem için de hashtag kullanımıdır. Paylaşım yapılan saatlerde ise pandemi süreciyle evde geçirilen saatlerin değişmesi ile iki dönem arasında farklılıklar olduğu gözlenmiştir.

Anahtar Kelimeler: İletişim, Sosyal Medya, Video on Demand (VOD), Twitter, Nicel İçerik Analizi. 


\title{
Video On Demand Platforms' Twitter Use as A Marketing Communication Strategy: A Research on Netflix Turkey During the Pre and Post Covid-19 Period
}

\author{
Dilek Melike Uluçay (Asst. Prof. Dr.) \\ Yaşar University Faculty of Communication \\ melike.taner@yasar.edu.tr \\ Güven Zararsız (Part Time Lect.) \\ Yaşar University Faculty of Communication \\ guven.zararsiz@yasar.edu.tr \\ Umut Can Aytekin (MA Student) \\ (iD) Yaşar University Institute of Social Sciences \\ umutcanaytekin@gmail.com
}

Date Received: 02.03.2021

Date Accepted: 24.05.2021

Date Published: 30.07.2021

https://doi.org/10.17680/erciyesiletisim.890011

\begin{abstract}
One of the areas where the development of media technologies is vividly observed is the tools, platforms and services consumed by the consumer for entertainment purposes. In particular, subscription-based "video on demand" (VOD) platforms are the ones that allow viewers to consume rich content via mobile technologies $24 / 7$. Netflix is a widely used VOD platform in the world. The company uses social media as a part of its main marketing communications. In this context, Twitter is the most frequently used medium of Netflix. This study aims to uncover how Netflix Turkey uses Twitter as a marketing communication tool. Additionally, this study questions whether the company has made changes in Twitter usage strategies in this period when consumers spend more time at home due to COVID-19. In this context, a total of 228 tweets of Netflix Turkey were analyzed by conducting quantitative content analysis. According to the results, Netflix mainly used Twitter shares to promote content in both periods. However, the most used plugin by the company is the use of hashtags for both periods. Moreover, there were differences in time periods of sharing as a result of the changes in the hours spent at home due to the pandemic.
\end{abstract}

Keywords: Communication, Social Media, Video on Demand (VOD), Twitter, Quantitative Content Analysis. 


\section{Giriş}

Medya teknolojileri geliştikçe, izleyicilerin medyayı tüketim ve medya ile etkileşim biçimleri de değişmiştir. Geleneksel yayıncılığın izleyiciye sunduğu zaman ve yer bağımlı içerikler, izleyicilerin zaman ve yerden bağımsız, herkesle her yerde paylaşabileceği içeriklere dönüşmüştür. Özellikle abonelik usulü hizmet veren "talebe yönelik" (video on demand) platformlar, izleyicilerin $7 / 24$ mobil teknolojiler üzerinden erişiminin bulunduğu zengin içerik tüketimine olanak vermektedir (Paz Perez, 2020). Aynı zamanda talebe yönelik hizmet veren bu platformlar, izleme pratiklerini de değiştirmiştir. İzlenme saatleri ve sürelerinin uzaması, aynı anda bir serinin birden fazla bölümünün izlenmesi gibi yeni izleyici alışkanlıkları, bu endüstrinin izleyicinin ihtiyaçlarına yönelik yeni teknik donanımlar ve hizmetler sunmasına yol açmıștır. Örneğin, "on demand" televizyonların öncüsü olarak kabul edilen Netflix, "açılışı geç" sekmesi ekleyerek izleyicilerin içeriği ileri oynatmadan giriş kısmını atlamasını sağlayabilmektedir (Matrix, 2014).

Yeni televizyonlar yalnızca izleyicinin içeriği tüketme alışkanlıklarını değil, aynı zamanda izleyicinin içeriği paylaşma alışkanlıklarını da etkilemiştir. Özellikle sosyal medya, izleyicilerin içeriklere dair paylaşımlarını ve yayın yapan platformlarla etkileșimini hızlandırmıştır. Buna bağlı olarak "video on demand" platformlar pazarlama stratejilerinde yoğun olarak sosyal medya pazarlamasını kullanmaya başlamıștır (Gómez \& Quevedo, 2018).

Netflix, 2019 Eylül ayında yapılan resmî açıklamaya göre dünyada 190 farklı ülkede 167 milyon ücretli kullanıcıya sahip, Türkiye'de ise 1.7 milyonun üzerinde tekil kullanıcıya sahip bir "video on demand" (VOD) platformdur ("Netflix Türkiye Abone"). Sektörün öncüsü ve lideri olan firma, sosyal medya pazarlama iletişimi stratejilerini yoğun bir şekilde kullanan, izleyici etkileşimine sunduğu hizmetin parçası gözüyle bakan bir yaklaşıma sahiptir. Firmanın özellikle Twitter özelinde izleyicisini harekete geçirmeyi ve izleme pratiklerini etkilemeye çalıştığı görülmektedir (Van Es, 2016).

Tüm bunlara ek olarak, 2020 yılının ilk çeyreğinde pandemi sebebiyle yaşanan ev karantinaları sonucu Netflix kullanıcı sayısında 16 milyonluk bir artış görülmüștür. Firma yetkililerinin açıklamalarına göre bu artış 2019 yılının son aylarının neredeyse iki katıdır (Thomas, 2020). Dünya genelinde yaşanan coronavirus salgını süreciyle, platformun toplam abone sayısının 203,7 milyona ulaştığı duyurulmuştur ("Netflix Güncel Abone"). $\mathrm{Bu}$ artışla ilișkili olarak platformun hem geleneksel pazarlama iletişimi stratejilerinde hem de sosyal medya kullanım stratejilerinde değişiklik ya da yenilik yapmış olabileceği düșünülmektedir.

Twitter, televizyon ağı pazarlama stratejilerine en sık dahil edilen sosyal medya platformlarından biridir ve ikinci ekran pazarlamasında merkezi bir rol oynamaktadır (Segado, Grandío \& Fernández-Gómez, 2015). Bu durumun sebeplerinden biri 2019 verilerine göre Twitter'ın dünya genelinde 330 milyon takipçisi olması ve etkileşime en çok olanak tanıyan sosyal medya platformlarından biri olmasıdır (Tankovska, 2021).

Bu çalıșmanın birincil amacı, Netflix Türkiye'nin bir sosyal medya pazarlama strateji aracı olarak Twitter platformunu nasıl kullandığını ortaya çıkarmaktır. Çalışmanın ikincil amacı ise Netflix Türkiye'nin Twitter kullanım stratejilerinin COVID-19 Pandemi süreci ile birlikte artan kullanıcı sayısı ve kullanım süresi sonucu değişiklik gösterip göstermediğini ortaya çıkarmaktır. Bununla birlikte, Netflix Türkiye Twitter takipçilerinin etkileşim eğilimleri de çalışma kapsamında incelen konular arasındadır. Bu amaçlar doğrultusunda, öncelikle 
VOD televizyonlar ve Netflix özelinde bilgiler verilmiş, ardından Twitter'ı Netflix özelinde sosyal medya pazarlama iletişimi stratejisi olarak inceleyen çalışmalar incelenmiştir. Yöntem bölümünde araştırma kapsamında Gómez ve Quevedo’nun (2018, s. 136-137) çalışmasından uyarlanan Twitter pazarlama stratejilerini ortaya çıkarmak için kullanılan kodlama cetveline ve kullanılan analizlere detaylı bir şekilde yer verilmiștir. Son olarak bulgular ve sonuç bölümlerinde çalışmanın bulguları tartışılmıştır.

\section{Video on Demad (Vod) Platformlar ve Netflix}

TVI, 1950’lerin ortalarından 1980’lerin başına kadar uzanan kanal kıtlığı ve kitle izleyicisinin hâkim olduğu dönem olarak adlandırılmaktadır. Yaklaşık olarak 1980'lerin başından 1990'ların sonuna kadar uzanan TVII, kanal sayılarının arttığı, kaliteli televizyon kanallarının yayına başladığı dönemdir. 1990'ların sonlarından günümüze uzanan TVIII dönemi ise dijital dağıtım platformlarının çoğaldığı ve daha fazla izleyici kategorisinin oluştuğu dönem olarak anılmaktadır. Netflix ve diğer VOD platformlarını da içine alabileceği VIV, izleme modellerinin, markalama stratejilerinin, farklı medya formlarının birbiriyle etkileşime girme biçiminin televizyon setinden çıkartılmasının çeşitli yollarının sunulduğu bir matris medya dönemi olarak nitelendirilmektedir (Jenner, 2016).

VOD platformlar arasında dünyanın en çok dijital film satışını yapan platformlardan biri olan ve 2016 verilerine göre 85.000 üzerinde filme erişim sağlayan Itunes, 2001 yılında IPOD cihazlarının piyasaya çıkmasıyla birlikte Apple şirketi tarafından tanıtılmıştır. 2003 yılında Windows sürümünün de ortaya çıkması ve içerisinde 200.000 müzik içeriğinin olduğu dijital bir müzik mağazasına dönüşmesiyle birlikte Itunes, ilk haftasında 1.000 .000 satış yapmıştır. Itunes, 2007 yılında ilk Iphone telefonun tanıtılması ve bununla birlikte video izleme özelliklerinin getirilmesiyle birlikte aynı zamanda bir VOD platforma dönüşmüştür (McElhearn, 2016).

2005 yılında Amazon tarafından kurulan başka bir VOD şirketi Amazon Prime ise aylık abonelik sistemiyle kullanıcılara HBO gibi önemli dizi ve film kanallarının içeriklerini sunmaktadır. Amazon Prime, dünyada çapındaki 150 milyonluk abonesi ile Netflix'in en önemli rakipleri arasında gösterilmektedir ("Amazon Prime Türkiye'de") 2015 yılı itibariyle dünyada bir milyar aktif aylık kullanıcısının olduğunu açıklayan Google Play ise bilgisayar, Android ve IOS işletim sistemlerinde kullanıcıların film indirmesine veya kiralamasına izin veren önemli bir diğer VOD platformudur (Liu, Au, \& Choi, 2014). Bunun dışında 2007 yılı itibariyle NBC şirket grubu tarafından kurulan ve içerisinde birçok güncel ve klasik TV dizilerini ve filmlerini barından Hulu da VOD platformlar arasında yer almaktadır. Itunes'a benzer bir sistemle çalışan Hulu'da film ve dizi yaratıcıları, kullanıcılara yapılan satışın \%50'sine sahiptir. Disney'e bağlı bir yayın platformu olan Hulu, yaklaşık 30 milyon kullanıcıya sahip bir platformdur ve 2021 yılı içerisinde ABD sınırlarını aşarak tüm dünyaya açılmayı planlamaktadır (Altan, 2020).

VOD platformların sayılarındaki ve yaygınlıklarındaki hızlı artış dikkat çekicidir. İzleyicinin etkileşim ve katılım şansı bulduğu bu platformlar aynı zamanda izleyiciye aktif bir rol vermiştir. Tüketici ve izleyicilerin değişen rolleri ve üreten gruplar haline gelmesi, bu ve benzeri platformların yaygınlaşacağı ve üye sayılarının hızla artamaya devam edeceği izlenimini vermektedir. Şu an için bu platformlar arasında ulaştığı coğrafya, abone sayısı ve içerik zenginliği açısından Netflix rekabette öncü görünmekte ve VOD platformlarının lideri konumunda bulunmaktadır. 


\subsection{Netflix}

Netflix, 1997 yılında bir DVD kiralama hizmeti olarak faaliyete başlamıştır. Başlangıç aşamasında, daha önce sinemalarda ve televizyonda gösterimini tamamlamış filmlerin ve programların, belirli bir zaman dilimi için kiralanabilmesini ve eve gönderilebilmesini sağlamıștır (McDonald, 2016). Platform 2007 yılında, toplam sayısı 90.000 olan film arşivinin 10.000'ini "Hemen İzle" modunda kullanıcılarına ücretsiz olarak sunmaya başlamıștır. 2010 yılında ise, kullanıcıların sınırsız film ve TV programı indirebilmelerine olanak sağlayan bir abonelik sistemine geçmiştir. Aboneler aylık 7,99 Amerikan Doları ve eve kargo hizmetiyle kiraladıkları her DVD bașına da 2 Amerikan doları karşılığında aboneliklerini sürdürebilmişlerdir. Bu sistemle Netflix, sinemada yayın sonrası ikinci bir monitör olarak düşünülen DVD teknolojisini dijitalleștirerek, bu dönemin sonunu getirmeye odaklanmış görünmektedir (Jenner, 2016)

Netflix platformu, 2017 yılı itibariyle şirketin içerik yatırımlarına 6 milyar dolar ayırmaya başlamış ve Eylül 2019 yılında içeriğinde 2300'den fazla film ve 1200'den fazla dizi bulundurmaya bașlamıştır (Sarı \& Sancaklı, 2020). Bugün Netflix'in geldiği konuma bakıldığında, 190'dan fazla ülkede 167 milyondan fazla ücretli üyeliğe sahip, çok çeşitli tür ve dillerde TV dizileri, belgeseller ve uzun metrajlı filmlerle dünyanın yüksek sayıda abonesine sahip olan bir "Video on Demand" şirketi olarak anılmaktadır (Goldsmith, 2020). Netflix'in, mobil cihazlarda indirilebilir olması ve hizmete her yerde erişilebilir olması bu mecrayı başarılı kılan sebeplerden biridir (McDonald, 2016). Üyeler istedikleri kadar, istedikleri zaman, istedikleri yerde, internete bağlı herhangi bir ekranda reklama maruz kalmadan bu içerikleri izleyebilmektedirler.

2020 yılının Nisan ayında yapılan resmî açıklamada Netflix'in Türkiye'de 1,7 milyon tekil kullanıcısı olduğu belirtilmiştir. Bunların içerisinde aile hesapları göz önüne alındığında, sayı 4 milyonun üzerine çıkmaktadır. Netflix, 2019 Eylül ayında yaptığı açıklamada Türkiye'deki Netflix üyelerinin \%77'sinin içerikleri akıllı telefonlarından izlediğini belirtmiştir ("Türk İzleyicisinin Netflix'teki”). Dünyada ve Türkiye'de bu genişlikte bir kitleye ulaşan bir VOD platformu olan Netflix'in başarısının sebeplerini ortaya çıkarmak adına, şirketin kullandığı sosyal medya pazarlama stratejilerini, özellikle sık sık kullandığı Twitter stratejilerini belirlemenin önemli katkısı olacaktır.

\section{Bir Pazarlama İletişimi Aracı Olarak Sosyal Medya ve Twitter}

Yeni medya platformlarında içerik üreticilerinin yeri, tek taraflı olmaktan çıkıp, kullanıcılarla etkileşim halinde olabildikleri çok taraflı bir konuma geçmiştir. Kullanıcıların tek taraflı bilgi akışından çıkarak oy kullanma, yorum yapma ve geri bildirim sağlama firsatına sahip olması, dijitalleşme ve internet teknolojisinin birleşmesiyle oluşan IPTV ve Social TV gibi yayın formatlarında, insanların aynı anda sosyal medya gruplarında televizyon izlemelerine ve arkadaşlarıyla içerik paylaşmalarına olanak tanımaktadır. Akıllı ve mobil cihazların çoğalmasıyla televizyon yayınlarını izleyen birey, sosyal ağlar üzerinden yayınla ilgili görüş ve eleştirilerini paylaşabilmekte ve 'ikinci ekran' adı verilen bu konsept ile etkileşim sağlayabilmektedir (Kırık \& Domaç, 2014).

İzleyicilerin ikincil ekranlar sayesinde izledikleri hakkında yorum yapma alışkanlıklarının gelişmesi, içerik üreticilerinin göz ardı etmemeleri gereken bir durum haline gelmiştir. İçerik üreticileri, kullanıcılarla etkileşimlerini arttırmak ve bununla birlikte marka bilinirliklerini arttırmak adına sosyal medya hesaplarını interaktif bir biçimde kullanarak önemli adımlar atmaya başlamışlardır. Twitter'ın da izleyiciler tarafından en çok tercih edilen ikincil ekran uygulaması haline gelmesi ile birlikte bu mecra, 
içerik üreticilerinin en çok önem verdiği sosyal medya platformlarından biri olmuştur (Gómez \& Quevedo, 2018)

Twitter bașta olmak üzere sosyal medya mecralarının televizyon yayıncıları tarafından ikinci ekran olarak etkin bir şekilde nasıl kullanılabileceğini araştıran Van Es (2016) çalışmasında dört temel kategoriden bahsetmiştir. Sosyal medyanın televizyon yayıncılığında kullanılabileceği dört kategori; tanıtıcı, duygusal, işlevsel ve ilişkisel işlev uygulamalardır. Sosyal medya, içeriği görüntüleyenleri bu içeriği retweetlemeye, paylaşmaya veya beğenmeye teşvik ediyorsa ve marka bilinirliğini artırma amacıyla kullanılıyorsa sosyal medyanın bir tanıtım aracı olarak kullanıldığı düşünülmektedir. Duygusal kategori ise izleyicilerin duygusal katılımlarını beslemeyi amaçlamaktadır. Bu yaklaşım, kitle katılımını ölçümlemeye de olanak sağlamaktadır. Örneğin, izleyicileri belirli konular hakkında tweet atmaya teşvik ederek bir sohbetin içine çekmek bu kategorideki kullanımlar arasında yer almaktadır. İşlevsel kullanım ise sosyal medyadan araç olarak dolaysız faydalanmayı hedeflemektedir. Örneğin, TV'deki bir yarışmaya adayları oylamak ya da direk katılım sağlamak amacıyla Twitter aracılığı ile belirli hastagler kullanılarak katılmak mümkün olabilmektedir. Son olarak ilişkisel işlev sosyal medyanın iletişimi açık ve sürdürülebilir kılma olanaklarından yararlanmayı hedeflemektedir. Bir dizinin ya da yarışma programının reklam arasına girmeden hemen önce reklamdan sonra oylarla kazananın izleyici tweetlerine göre paylaşılacağını duyurması, izleyicilerin reklamdan ya da bölümlerden sonra ekran karşına geri gelmesini sağlayabilmektedir (Van Es, 2016)

Twitter, TV yayıncılığına ek olarak VOD platformlar için de önemli avantajlar sağlamaktadır. VOD platformlar için bu avantajlardan biri; özellikle dizi içerikleri için bölüm bazında ya da sezon bazında hashtag kullanımlarıyla yalnızca kendi takipçilerine değil, hashtag popülerliğinin artmasıyla kendi takipçileri dışındaki Twitter kullanıcılarının da görebileceği ve tek tıkla ulaşabileceği bir konumda reklam yapabilme imkânı vermesidir (Dooms, Pessemier, \& Martens, 2013). Bunun dışında Twitter'ın “Developer Account" özelliğiyle birlikte, dizi ve film yapımcılarının bu hashtag üzerinde detaylı analiz yapmalarına izin veren bir veri paylaşımı yapması, onları film ve dizi içeriklerinin olumlu ve olumsuz geri dönüşlerini takip edebilme ve yeri geldiğinde gelen yorumlara göre yönlendirme yapabilmesine de imkân sağlamaktadır.

Twitter'ın sıkça faydalanılan iletişim avantajlarından biri de elektronik ağızdan ağza iletişime (eWOM) imkân vermesidir. Bu sebeple, birçok marka Twitter üzerinden hedef kitleleriyle etkileşime girmeye başlamıştır. Tüketicilerin mal ve hizmetler hakkındaki yorumlarını özgürce paylaşmaları için yeni bir fırsat haline gelen eWOM (Chevalier \& Mayzlin, 2006) internetin gücünü kullanarak daha fazla kişiye ulaşma açısından WOM'dan daha faydalı olarak değerlendirilmiştir (Chatterjee, 2001). Twitter sayesinde mal ve hizmetlerinin farkındalığını artırmak amacıyla firmaların bu platform üzerinden tüketicilerle iletişim kurması, Twitter'ın eWOM'un gelişmesine yol açan ve hızla yayılan bir araç olarak görülmesine sebep olmuştur (Asur \& Huberman, 2010). Markaların geçmiş ve mevcut durumu, bağlantı paylaşımı, mal ve hizmetleri ile ilgili bilgiler hakkında firmalar tarafından Twitter üzerinde sıkça paylaşılan bilgiler arasında yerini almıştır (Kwon, Kim, Sung, \& Yoo, 2015).

Twitter, aynı zamanda kullanıcıların online ortamdaki hareketlerini arttırmak için markanın resmî web sitesine yönlendirmek, böylelikle marka mesajlarını etkin bir şekilde yaymak ve hedef kitlesindeki kanaat lideri hesaplarıyla etkileşimi kolaylaştırmak gibi işlevlere de hizmet etmeye başlamıştır (Huberman, Romero, \& Wu, 2009). Diğer yandan, 
tüketicilerin markalarla ilgili talep ve şikayetlerine hızla ulaşma yeteneği, Twitter'ı kullanıcılar için ideal bir iletişim ve etkileşim platformu haline getirmiştir. Böylece marka iletişimine tüketici katılımının artmasıyla, markaların özelleştirilmiş ve kişiselleştirilmiş marka iletişimi yürütmesi mümkün hale gelmiştir (De Bryun \& Lilien, 2008).

Son yıllarda gündelik hayatın ayrılmaz bir parçası olan sosyal medya platformları 2019 yılında COVID-19 pandemi sürecinin ardından olağan yaygınlık ve kullanıcı sayılarındaki artış seyrini kaybederek, beklenenin çok üzerinde insana ulaşmaya başlamıştır. Özellikle pandemi sürecini ev karantinası konusunda daha sıkı tedbirler alarak geçiren ülkelerde bu artış diğerlerinden daha dikkat çekici olmuştur. "We are social" 2020 raporuna göre 2019 Nisan ayından 2020 Nisan ayına kadar geçen sürede internet ve sosyal medya kullanıcı sayılarına 300 milyon yeni kişi eklenmiştir. Rapora göre bugün dünyada 4,57 milyar insan internet ve 3,8 milyar insan da sosyal medya kullanmaktadır. 2020 yılında ulaşılan bu rakamlar bir önceki yıla göre yaklaşık \%8'lik bir artış göstermiş durumdadır. Diğer önemli bir veri ise güncel internet kullanıcılarının \%34'ünün pandemi öncesi döneme göre daha sık olarak akıllı televizyon ve VOD platformları kullandıklarını belirtmeleridir. Netflix'in yapmış olduğu açıklamaya göre firma Nisan 2019'dan Nisan 2020'ye kadar geçen sürede en hızlı büyüme ve izleyici etkileşimine ulaşmış durumdadır. Twitter ise bu süreçte en belirgin çıkışı yaşayan sosyal medya platformları arasında yer almaktadır. "We are social" 2020 raporuna göre Twitter bir yıl öncesine göre 47 milyon daha fazla kişiye ulaşmıştır ("Digital Around the World").

Tüm bu gelişmeler sebebiyle, hızlı bir yükseliş eğilimine sahip olan Netflix'in pazarlama iletişiminin çok güçlü araçlarından biri olan Twitter'ın, pandeminin sebep olduğu değişen tüketici davranışlarını ve alışkanlıklarını gözeterek nasıl kullandığını incelemek önem taşımaktadır.

\section{Yöntem}

Bu çalışmanın amacı Netflix Türkiye'nin Twitter'ı bir pazarlama iletişim aracı olarak nasıl kullandığını ortaya çıkarmaktır. Çalışmanın bir diğer amacı COVID-19 pandemi süreciyle tüketicilerin evde daha çok vakit geçirmeleri sebebiyle artan Netflix ve Twitter kullanımlarının firmanın kullandığı pazarlama iletişimi stratejilerinde değişiklik yaratıp yaratmadığını ortaya çıkarmaktır. Bu amaç doğrultusunda çalışmada, nicel içerik analizi kullanılmıştır. Nicel içerik analizi iletişim içeriğinin maddeler halinde gruplanması, her maddenin bir kategoriyle ilişkilendirilmesi ve her kategori için ise sayısal olarak bir değer belirlenmesi anlamına gelmektedir (Rouke, 2004). Sayısal değer olarak daha yüksek olan maddelerin ilişkilendirildikleri kategoriyle bağlantısının daha kuvvetli olduğu varsayılmaktadır.

Çalışma kapsamında sosyal medya platformları arasından Twitter'ın inceleme konusu olarak seçilmesinin birkaç önemli sebebi bulunmaktadır. Öncelikle, televizyon ağı pazarlama stratejilerine en sık dahil edilen sosyal medya platformu Twitter'dır. Diğer yandan, ikinci ekran pazarlamasında Twitter merkezi bir rol oynamaktadır (Segado, Grandío, \& Fernández-Gómez, 2015).

\section{1. Örneklem}

Çalışmanın örneklemini Netflix Türkiye tarafından @netflixturkiye Twitter hesabında 11.01.2020 - 11.05.2020 tarihleri arasında yayınlanan toplam 228 paylaşım oluşturmaktadır. Firmanın belirtilen dönem aralığındaki tüm paylaşımları örnekleme dahil edilmiştir. Bu örneklem grubunu oluşturan zaman aralığı, Türkiye'de resmi olarak 
açıklanan ilk Covid-19 vaka tarihi olan 11.03.2020 dikkate alınarak, bu tarih öncesi ve sonrasındaki 2 ayı kapsayacak şekilde belirlenmiștir.

\subsection{Veri Toplama Aracı}

Örneklem belirlendikten sonra nicel içerik analizinde kullanılacak olan kodlama cetvelini belirleme aşamasına geçilmiştir. Bu süreçte, benzer nitelikte bir araştırma gerçekleştirmiş olan Gomez ve Quevedo' nun (2018) araștırmaları için geliştirdikleri kodlama cetvelindeki kategoriler ve maddeler, belirli özellikleriyle bu çalışmaya uyarlanmıştır. Uyarlanan kodlama cetvelinin içeriği Tablo 1'de verilmiştir. Kodlama cetvelinde listelenen maddeler sayısal bir değer verilerek kodlanmıştır ( $1=$ var, $0=$ yok). Buna göre örneklem kapsamındaki her bir paylaşım için kodlama cetvelinde yer alan maddeler var (1) ve yok (0) olarak kodlanmıştır. Paylaşımların tanımlayıcı özellikleri için de tweet metni, tarihi ve saat dilimi kodlanmıştır. Saat dilimi için referans kodlama çizelgesindeki gibi bir gün 10 farklı zaman dilimine bölünmüştür. Kullanıcı etkileşimleri için yanıt, retweet ve beğeni değerleri sütun altına sayısal olarak kodlanmıștır ve analiz yapılırken ortanca değeri göz önünde bulundurulmuştur.

Tablo 1. Kodlama Cetveli

\begin{tabular}{|l|l|}
\hline $\begin{array}{l}\text { Paylaşımının } \\
\text { tanımlayıcı özellikleri }\end{array}$ & - Metin \\
\hline & - Parih (gün, saat) \\
- GF (Kutlami sağlayan): Netflix servisleriyle ilgili haber veya açıklama içeren. \\
- AS (Anket duyurusu): Twitter anketine katılıa daveti içeren. \\
- M (Satın alma): Netlix servisi satın alma daveti içeren. \\
- PG (Oyun oynama): Bir oyun oynamaya veya teste katılmaya davet içeren. \\
- PB (Marka tanıtımı): Platformun kendi reklamını yaptığı paylaşımları \\
Kategoren. Örneğin; Sadece Netflix'te gibi metinler içeren. \\
içer \\
- PC (İçerik tanıtımı): Dizi, film veya belgesel gibi içeriklerin tanıtımlarını içeren. \\
- PE (Etkileşim yaratma): Takipçileri bir tartışmaya veya soru cevaplamaya davet içeren \\
- O (Diğer)
\end{tabular}

\section{3. İstatistiksel Analizler}

Çalışmada tanımlayıcı istatistiklerden faydalanılmış, verilerin frekans ve yüzde değerleri incelenmiștir. Verilerin analizi TURCOSA (https://turcosa.erciyes.edu.tr/, Erciyes University, Turkey) istatistik yazılımı ile gerçekleştirilmiştir.

\section{Bulgular}

Günlere ve saatlere göre atılan tweet yüzdeleri Tablo 2'de verilmiştir. Toplam değerler göz önüne alındığında Netflix Türkiye'nin Twitter mecrasında paylaşım yapmak için \%21,9 oranla en çok $18.00-20.00$ ve $21.00-00.00$ saat aralıklarını tercih ettiği görülmektedir. Tweetlerin hafta içi ya da hafta sonu gönderilmesinin COVID-19 öncesi ve sonrasında her ne kadar frekans açısından artış sergilediği görülse de yüzde bakımından 
değerlendirildiğinde belirgin bir değişiklik göstermediği gözlenmiştir. Ancak genel olarak Netflix Türkiye'nin Twitter'ı daha sık olarak hafta içi günler paylaşım yapmak için tercih ediyor olmasının sebebi, kullanıcıların Netflix izleme eğilimlerinin daha yoğun olarak hafta sonu olduğunun gözlenmesi olabilir. Hafta içi diziler ve platformun diğer içerikleri ile ilgili tanıtım yapmak, kullanıcı etkileșimi yaratmak ve eWOM yaratarak hafta sonu izlenme yakaladığı içeriklere dikkat çekmek ve hafta sonu izleyici sayısını arttırmak platformun tercih ettiği bir strateji olarak yorumlanabilir.

Saatler açısından incelendiğinde ise, 09:00-13:00 ile 16:00-18:00 ve 18:00-20:00 zaman aralıklarında atılan tweet yüzdelerinde dikkat çekici bir değişim gözlenmiştir. COVID-19 öncesi 09:00-13:00 zaman aralığında tweet yüzdesi \%21 iken, COVID-19 sonrasında \%10, 2'ye düşmüştür. Bu sonuçlara dayanarak, Netflix'in Twitter kullanım stratejisinin pandemi sonrası değiştiği çıkarımı yapılabilir. Pandemi öncesi günün erken saatlerinde yapılan Netflix paylaşımları, özellikle çalışan takipçiler tarafından öğle saatlerine günlük, sosyal iletişimde konuşma malzemesi olabilirken, böylece WOM'a ya da eWOM'a yol açabilecekken, pandemi sonrası kullanıcıların evden çalışma pratikleri ve gündelik sosyal iletişim saat aralıklarında değişiklik olmuş olabileceği çıkarımı yapılabilir. Diğer yandan, evde geçen sürenin artması ve evden çalışma pratikleri, kullanıcıların sosyal medya kullanımı başlangıç saatlerinin daha geç zaman dilimlerine kaymış olabileceği ihtimalini düşündürmektedir. Bu durum esnek çalışan ya da çalışmayan kullanıcılar için güne geç saatlerde başlama durumu ile ilişkilendirilebilecekken, çalışan kullanıcılar için evden çalışma uygulamaları doğrultusunda yoğun çalışma saatlerinin daha erken zaman aralığına kaymıș olabileceğini düşündürmektedir.

Diğer yandan, COVID-19 öncesi 16:00-18:00 zaman aralığında tweet yüzdesi \%6,2 iken, COVID-19 sonrasında \%23,1'e yükselmiştir. Bu artış, kullanıcıların yoğun olarak sosyal medya kullanımına öğleden sonra başlıyor olabileceklerini düşündürmektedir. $\mathrm{Bu}$ saatlerde Netflix paylaşımlarına maruz kalan takipçiler, yaygın olarak çalışma saatlerinin sona erdiği 18:00 sonrası kendi sosyal paylaşımlarında Netflix içeriklerini retweet edebilmektedir ya da yorum, beğeni yapabilmektedir. Bu durum Netflix platformunun Twitter'ı kullanıcı etkileșimi bakımından önemli bir stratejik araç olarak kullandığını düşündürmektedir.

COVID-19 öncesi 18:00-20:00 zaman aralığında tweet yüzdesi \%29,6 iken, COVID-19 sonrasında \%17,7'ye düşmüştür. Bu saat aralığı Netflix'in daha çok izlenme olasılığı olan saatler olarak değerlendirildiğinde, bu saat aralığındaki paylaşımların, izleyicinin ikinci ekran kullanımına da yönelebileceği düşüncesiyle Twitter'ın yine izleyici etkileşimi yaratmak adına kullanıldığını düşündürmektedir. Pandemi sonrası yüzde olarak bu saat aralığında Netflix'in paylaşım oranının düşmüş olması ise takipçilerin mecrayı izleme ve sosyal medyayı kullanım zaman dilimlerinin farklılaşması ile açıklanabileceği düşünülmektedir. Diğer saatler için tweet yüzdelerinde belirgin bir değişim gözlenmemiștir. 00:00-02:30 zaman aralığında COVID-19 öncesi ve sonrası herhangi bir tweet atılmamıştır.

Netflix Türkiye'nin Twitter üzerindeki paylaşımları COVID-19 öncesi ve sonrası süreçte frekans bazında belirli zaman aralıklarında farklılıklar gösterse de firmanın paylaşımlarını yaygın bir saat dilimi aralığında yaptığını, hafta içi ve hafta sonu günlerde benzer şekilde günlere yayılan paylașımlar yaptığını söylemek mümkündür. Bu kullanım sıklığı ve yaygınlığı, firmanın genel stratejisi olan her yerde ve her zaman kullanım imkanı ile tutarlı bir durum ortaya çıkarmaktadır. 
Tablo 2. Günlere ve Saatlere Göre Atılan Tweet Yüzdeleri

\begin{tabular}{|l|c|c|c|}
\hline Zaman & COVID-19 Öncesi (n=81) & COVID-19 Sonrası (n=147) & Toplam \\
\hline Gün & $\mathbf{n} \%$ & $\mathbf{n}$ \% & $\mathbf{n} \%$ \\
\hline Hafta içi & $62(76.5)$ & $103(70.1)$ & $165(72.4)$ \\
Hafta sonu & $19(23.5)$ & $44(29.9)$ & $63(27.6)$ \\
\hline Saat & $\mathbf{n} \%$ & $\mathbf{n} \%$ & $\mathbf{n} \%$ \\
\hline 07:30-09:00 & $0(0.0)$ & $1(0.7)$ & $1(0.4)$ \\
09:00-13:00 & $17(21.0)$ & $15(10.2)$ & $32(14.0)$ \\
13:00-15:00 & $1(1.2)$ & $9(6.1)$ & $10(4.4)$ \\
15:00-16:00 & $4(4.9)$ & $4(2.7)$ & $8(3.5)$ \\
16:00-18:00 & $5(6.2)$ & $34(23.1)$ & $39(17.1)$ \\
18:00-20:00 & $24(29.6)$ & $26(17.7)$ & $50(21.9)$ \\
20:00-21:00 & $11(13.6)$ & $26(17.7)$ & $37(16.2)$ \\
21:00-00:00 & $19(23.5)$ & $31(21.1)$ & $50(21.9)$ \\
00:00-02:30 & $0(0.0)$ & $0(0.0)$ & $0(0.0)$ \\
02:30-07:30 & $0(0.0)$ & $1(0.7)$ & $1(0.4)$ \\
\hline
\end{tabular}

Kategorilere göre atılan tweet yüzdeleri Tablo 3'te verilmiştir. Buna göre Netflix Türkiye'nin Twitter mecrasında en çok içerik tanıtımına yönelik paylaşım yaptığı görülmüştür. İçerik tanıtımına dair yapılan paylaşımlar, toplam paylaşımların \%82,9'unu oluşturmuştur. Aynı zamanda, Netflix'in içerik tanıtımına dair yaptığı paylaşımların tamamı kendi orijinal yapımı olan içeriklerdir. Bu bulgu Netflix'in kendisini rakiplerinden ayrıştırmak adına yalnızca bir VOD platformu olmadığını aynı zamanda kendi prodüksiyonlarıyla da fark edilmek istendiğini göstermektedir. Bu paylaşımları, \%33,8 ile Netflix'in kendi marka tanıtımına yaptığı içerikler ve \%27,2 ile etkileşime teşvik eden tweetler takip etmektedir. Netflix'in kendi marka tanıtımı için yaptığı paylaşımların çoğunluğu Netflix üyesi olmanın avantajlarına işaret ederken, etkileşime teşvik eden paylaşımları yine platformun eWOM'a ne kadar önem verdiğini işaret etmektedir.

Bilgi sağlayan ve etkileşime teşvik eden kategoriler için tweet yüzdelerinin COVID-19 öncesi ve sonrası dönemde farklılık gösterdiği gözlenmiştir. Diğer kategoriler için iki dönem arasında belirgin bir farklılık gözlenmemiştir. COVID-19 öncesi bilgi sağlayan içeriklerin tweet yüzdesi \%1,2 iken, COVID-19 sonrasında \%8, 8'e yükselmiştir. COVID-19 öncesi etkileşime teşvik eden içerikler için tweet yüzdesi \%17, 3 iken, COVID-19 sonrasında \%32,7’ye yükselmiștir. Bu bulgular COVID-19 sonrası dönemde platformun üye sayısının artmıș olması ve platformun izlenme süresinin uzamıș olması ile ilişkilendirilebileceği düşünülmektedir.

Tablo 3. Kategorilere Göre Atılan Tweet Yüzdeleri

\begin{tabular}{|l|c|c|c|}
\hline Kategori & Covid-19 Öncesi $\mathbf{n = 8 1}$ (\%) & Covid-19 Sonrası $\mathbf{n = 1 4 7 ~ ( \% ) ~}$ & Toplam \\
\hline PI (Bilgi sağlayan) & $1(1.2)$ & $13(8.8)$ & $14(6.1)$ \\
GF (Kutlama mesajı) & $1(1.2)$ & $0(0.0)$ & $1(0.4)$ \\
AS (Anket duyurusu) & $0(0.0)$ & $0(0.0)$ & $0(0.0)$ \\
M (Satın alma) & $0(0.0)$ & $0(0.0)$ & $0(0.0)$ \\
PG (Oyun oynama) & $0(0.0)$ & $0(0.0)$ & $0(0.0)$ \\
PB (Marka tanıtımı) & $28(34.6)$ & $49(33.3)$ & $77(33.8)$ \\
PC (İçerik tanıtımı) & $66(81.5)$ & $123(83.7)$ & $189(82.9)$ \\
PE (Etkileşim yaratma) & $14(17.3)$ & $48(32.7)$ & $62(27.2)$ \\
O (Diğer) & $0(0.0)$ & $0(0.0)$ & $0(0.0)$ \\
\hline
\end{tabular}

*Veriler $n(\%)$ olarak ifade edilmiștir. 
Eklenti öğelerine göre tweet yüzdeleri Tablo 4'te verilmiştir. Buna göre Netflix Türkiye'nin Twitter mecrasında en çok kullandığı eklentinin \%48,7 ile hashtag olduğu görülmüștür. Bunu \%30,7’yle fotoğraf ve \%27,6 ile video kullanımı takip etmektedir. Netflix, bu eklenti öğelerini görünürlügünü arttırmak ve viral etki yaratmak adına kullanmaktadır. Burada hashtag kullanımının öne çıkma sebebi, Netflix'in orijinal yapımları için hashtag kullanımını yoğun olarak kullanması ve böylelikle hem markayı hem de paylaşım yaptığı içeriği öne çıkarabilmesidir. Diğer bir ifadeyle, Nwtflix'in hashtag kullanımı kurumsal sosyal medya stratejisinin bir parçasıdır denilebilir.

Diğer taraftan, video eklentisi için tweet yüzdelerinin COVID-19 öncesi ve sonrası değişim gösterdiği gözlenmiştir. COVID-19 öncesi video eklentisi için tweet yüzdesi \%42 iken, COVID-19 sonrasında \%19,7'ye düşmüştür. Bu noktada azalan video eklentisinin yerini hashtag kullanımının aldığı söylenebilir. Pandemi dönemi için platformun yeni orijinal içeriklerle kullanıcı karşısına çıkmasının ve bu yeni içeriklerin görünür olmasını ve öne çıkmasını tercih etmesinin rolü olabilir.

Tablo 4. Eklenti Öğelerine Göre Tweet Yüzdeleri

\begin{tabular}{|l|c|c|c|}
\hline Eklenti Öğeleri & Covid-19 Öncesi $\mathbf{n = 8 1 ~ ( \% ) ~}$ & Covid-19 Sonrası n=147 (\%) & Toplam \\
\hline LinkSm (Netflix websitesi) & $4(4.9)$ & $16(10.9)$ & $20(8.8)$ \\
LinkWb (Diğer websitesi) & $1(1.2)$ & $5(3.4)$ & $6(2.6)$ \\
Gif & $0(0.0)$ & $2(1.4)$ & $2(0.9)$ \\
Fotoğraf & $22(27.2)$ & $48(32.7)$ & $70(30.7)$ \\
Video & $34(42.0)$ & $29(19.7)$ & $63(27.6)$ \\
Emoji & $11(13.9)$ & $27(18.4)$ & $38(16.8)$ \\
Hashtag & $34(42.0)$ & $77(52.4)$ & $111(48.7)$ \\
\hline
\end{tabular}

Kullanıcı etkileşimine göre tweet sayılarının Türkiye'de COVID-19 öncesi ve sonrası değişimi Tablo 5'te verilmiştir. Buradaki veriler ortanca, en küçük ve en büyük değer ile özetlenmiştir. Yanıt sayısı için tweet sayılarının COVID-19 öncesi ve sonrası belirgin biçimde değiştiği gözlenmiştir. Yanıt sayılarında COVID-19 sonrası gözlenen artış, büyük oranda platformun hem kullanıcı hem takipçi sayısındaki artışla ilişkilendirilebilir. Diğer yandan, kullanıcıların artan ekran ve sosyal medya kullanım süresi, etkileşim pratiklerine de doğrudan yansımış görünmektedir. Netflix'in yapmış olduğu açıklamaya göre firma Nisan 2019'dan Nisan 2020'ye kadar geçen sürede en hızlı büyüme ve izleyici etkileşimine ulaşmış durumdadır. Twitter ise bu süreçte en belirgin çıkışı yaşayan sosyal medya platformları arasında yer almıştır. "We are social" 2020 raporuna göre Twitter bir yıl öncesine göre 47 milyon daha fazla kişiye ulaşmıştır ("Digital Around the World").

Tekrar tweet (reteweet) ve beğeni sayıları içinse dikkat çekici bir fark olmadığı görülmüştür. COVID-19 öncesi yanıt sayısı için tweet ortancası 79 iken, covid-19 sonrasında 111'e yükselmiştir.

Tablo 5. Kullanıcı Etkileşimine Göre tweet Yüzdelerinin COVID-19 Öncesi ve Sonrası Değişsimi

\begin{tabular}{|l|c|c|c|}
\hline Kullanıcı Etkileşimi & Covid-19 Öncesi $(\mathbf{n = 8 1})$ & Covid-19 Sonrası $(\mathbf{n = 1 4 7})$ & Toplam \\
\hline Yanıt sayısı & $79(0-564)$ & $111(1-4300)$ & $90(0-4300)$ \\
Tekrar tweet sayısı & $85(9-3800)$ & $107(3-5900)$ & $100(3-5900)$ \\
Beğeni sayısı & $2900(246-42900)$ & $4300(194-99900)$ & $3250(194-99900)$ \\
\hline
\end{tabular}




\section{Sonuç}

Bu çalışmanın amacı Netflix Türkiye'nin Twitter'ı bir pazarlama iletişim aracı olarak nasıl kullandığını ortaya çıkarmaktır. Aynı zamanda çalışma kapsamında pandemi sebebiyle yaşanan ev karantinaları sonucu Netflix'in Twitter kullanım stratejilerinde değişiklik yapıp yapmadığı incelenmiştir.

Çalıșmanın bulgularına göre Netflix Türkiye hesabında 11 Ocak 2020 ve 11 Mayıs 2020 tarihleri arasında paylaşllan toplam tweetlerin; \%36,84'ünü oluşturan 84 tweet COVID-19 vakası görülmeden önceki (Ocak-Şubat 2020) 2 ayda atılırken, \%63,16'sını oluşturan 144 tweet ise COVID-19 vakası görüldükten sonraki (Nisan-Mayıs) 2 ayda atılmıștır. Bunun en önemli sebebi, insanların karantina kararıyla birlikte evde zaman geçirmeleri ve içerik izleme alışkanlıklarının artması olarak düşünülmektedir. Bununla birlikte, firma her iki dönemde de Twitter'ı yoğun olarak içerik tanıtımı yapmak amacıyla kullanmıștır.

Netflix Türkiye'nin Twitter mecrasında en çok kullandığı eklentinin \%48,7 ile hashtag olduğu görülmüștür. Video on Demand (VOD) platformların Twitter mecrasını aktif kullanmasının ana sebeplerinden biri mecranın etkileşime en çok olanak sağlayan mecralardan biri olmasıdır. Bununla birlikte, Twitter üzerindeki hashtag kullanımlarıyla, VOD platformlar birincil hedef kitleleri dışında potansiyel hedef kitlelere de ulaşma imkânı yakalayabilmektedir. Benzer sebeplerle, Netflix Türkiye de Twitter kullanımını tercih etmiştir.

COVID-19 sonrasında prime-time'ların değişime uğramasıyla atılan tweetlerin zamanlarında da değișiklikler olduğu saptanmıștır. COVID-19 öncesi 09:00-13:00 zaman aralığında tweet yüzdesi \%21 iken, COVID-19 sonrasında \%1,2'ye düșmüștür. Bunun sebeplerinden birinin alınan karantina kararıyla birlikte hedef kitlenin uyku saatlerindeki değişiklik olduğu düşünülmektedir.

COVID-19 öncesi 16:00-18:00 zaman aralığında tweet yüzdesi \%6,2 iken, COVID-19 sonrasında \%23,1'e yükselmiștir. İş hayatının normal seyrettiği zamanlarda 16:00-18:00 saat aralı̆̆ı, insanların ișten eve geldiği zaman olarak değerlendirildiği için bu saatlerde hedef kitlenin işte veya trafikte olduğu düşünülerek paylaşım yapılmaması tercih edilirken, görülen COVID-19 vakaları sonucunda alınan karantina kararıyla birlikte, insanların bu zaman dilimini evde geçirdikleri göz önünde bulundurulmuştur ve bu zaman diliminde atılan tweetlerde artış olduğu gözlemlenmiştir.

Pandemi koşullarının devam etmesi, ev karantinalarının sürmesi, yaşamın farklı alanlarına sınırlandırmalar getirilmesi hiç şüphesiz tüketici davranışlarında belirgin değişimlere yol açmıştır. Evde geçirilen zamanın artması, ekran başında bulunma süresinin uzaması, eğlence anlayışının dışarıdan içeriye taşınması Netflix gibi diğer VOD platformlarının da çeşitlenmesine, yaygınlaşmasına ve talep edilirliğinin artmasına yol açmıştır. Artan talep ve değișen tüketici davranışları ile bu mecraların yeni pazarlama iletişimi yaklaşımları olarak kullanılmasına yol açabilmektedir. Diğer yandan, pandemi koşulları sürerken tüm alanlarda yaşanan değişimler hiç şüphesiz pazarlama iletişimi, tüketici davranışları, davranış bilimleri ve yenilikçi yaklaşımların artan bir şekilde araştırılmaya devam etmesine yol açacaktır.

Bu araştırma Netflix Türkiye'nin Twitter hesabında 11.01.2020 - 11.05.2020 tarihleri arasında yayınlanan toplam 228 paylaşımıyla sınırlıdır. Kullanıcıların Netflix'in paylaşımlarına yaptığı yorum ve beğeniler çalışmanın dışında bırakılmıştır. Bununla birlikte, firmanın diğer sosyal medya hesaplarındaki paylaşımları da incelenmemiştir. 
İlerleyen çalışmalar, Netflix'in diğer ülkelerdeki Twitter paylaşımlarını da araştırma konusu yaparak, farklı hedef kitleleri kapsayan karşılaştırmalı bir yapıda tasarlanabilir. Diğer taraftan, takipçi yorumları incelenerek, firmanın paylaşımlarının etkisi incelenebilir ve alıcı özelinde bir araştırma yapılabilir. Son olarak firmanın yalnızca Twitter hesabı değil diğer sosyal medya hesaplarındaki paylaşımları da incelenerek, farklı mecralarda takip ettiği stratejiler kıyaslamalı bir yaklaşımla tartışılabilir.

\section{Kaynakça}

Altan, S. (2020, Nisan). Disney Plus 50 milyon aboneyi geçti. Pazarlamasyon. Erişim adresi: https://pazarlamasyon.com/disney-plus-50-milyon-aboneyi-gecti/

Asur, S., \& Huberman, B. (2010, Ağustos). Predicting the future with social media [Öz] 2010 IEEE/WIC/ACM International Conference on Web Intelligence and Intelligent Agent Technology konferansinda sunulan bildiri, IEEE: Toronto. doi:10.1109/WI-IAT.2010.63

Amazon Prime Türkiye'de: Hangi hizmetleri sunuyor, Rakiplerine Göre Nasıl bir Performans Sergiliyor? (2020, 15 Eylül). BBCNEWS Türkçe. Erişim adresi: https:// www.bbc.com/turkce/haberler-dunya-54165604

Chatterjee, P. (2001). Online reviews: Do consumers use them? [Öz] Association for consumer research konferansında sunulan bildiri, ARC: Austin. Erişim adresi: https://papers.ssrn.com/sol3/papers.cfm?abstract_id=900158

Chevalier, J., \& Mayzlin, D. (2006). The effect of word of mouth on sales: Online book reviews. Journal of Marketing Research, 43(3) 345-354. doi: 10.1509/ jmkr.43.3.345

De Bryun, A., \& Lilien, G. (2008). A multi-stage model of word-of-mouth influence through viral marketing. International Journal of Research in Marketing, 25(3), 151-163. doi:10.1016/j.ijresmar.2008.03.004

Türk İzleyicisinin Netflix’teki İçerik Tüketim Alışkanlıkları (2019, 4 Eylül). Digitalage. Erişim adresi: https://digitalage.com.tr/turk-izleyicisinin-netflixteki-iceriktuketim-aliskanliklari/

Netflix Güncel Abone Sayısını Açıkladı (2021, Ocak 20). Digitalage. Erişim adresi: https://digitalage.com.tr/netflix-guncel-abone-sayisini-acikladi/

Netflix Türkiye Abone Sayısı ve Elde Edilen Gelir Açıklandı (2021, 20 Ocak). Digitalage. Erişim adresi: https://digitalage.com.tr/netflix-guncel-abone-sayisini-acikladi/

Dooms, S., De Pessemier, T., \& Martens, L. (2013, Ekim). Movie tweetings: a movie rating dataset collected from twitter. Workshop on Crowdsourcing and human computation for recommender systems, CrowdRec at RecSys (Vol. 2013, p. 43).

Goldsmith, J. (2020, Mart 4). Streaming Study Finds Netflix, Hulu Led In New. Deadline. Erişim adresi: https://deadline.com/2020/03/streaming-study-finds-netflixhulu-led-new-subscriptions-1202874044/

Gómez, E. F., \& Quevedo, J. M. (2018). Connecting with audiences in new markets:. Journal of Media Business Studies, 15(2), 127-146. doi:10.1080/16522354.2018.1 481711 
Huberman, B., Romero, D., \& Wu, F. (2009). Social Networks That Matter: Twitter Under the Microscope. First Monday, 1-5. https://arxiv.org/abs/0812.1045 adresinden alındı

Jenner, M. (2016). Is this TVIV? On Netflix, TVIII and Binge-watching. New Media and Society, 18(2), 257-273. doi:10.1177/1461444814541523

Kırık, A. M., \& Domaç, A. (2014). Sosyal medya üzerinden televizyon reyting ölçümlerinin bir analizi: Twitter örneği . Akademik Sosyal Araştırmalar Dergisi, 2(5), 414-430.

Kwon, E. S., Kim, E., Sung, Y., \& Yoo, C. (2015). Brand followers: Consumer motivation and attitude towards brand communications on Twitter. International Journal of Advertising, 33(4), 657-680. doi:10.2501/IJA-33-4-000-000

Liu, C. Z., Au, Y. A., \& Choi, H. S. (2014). Effects of freemium strategy in the mobile app market: An empirical study of Google Play. Journal of Management Information Systems, 31(3), 326-354. doi: 10.1080/07421222.2014.995564

Matrix, S. (2014). The Netflix effect: Teens, binge watching, and on-demand digital media trends. Jeunesse: Young People, Texts, Cultures, 6(1), 119-138. doi: 10.1353/ jeu.2014.0002

McDonald, K. (2016). From Online Video Store the Global Internet TV Network: Netflix and the Future of Home Entertainment. K. McDonald, K. McDonald, \& D. SmithRowsey (Ed.) içinde, The Netflix Effect: Technology And The Entertainment in the 21st Century (s. 203-218). New York: Bloomsbury Acedemic.

McElhearn, K. (2016, 9 Ocak). 15 years of iTunes: A look at Apple’s Media app and Its Influence on an Industry. Macworld. Erişim adresi: https://www.macworld. com/article/3019878/15-years-of-itunes-a-look-at-apples-media-app-and-itsinfluence-on-an-industry.html

Paz Perez, E. (2020). Next episode, next market: social media marketing for SVOD, the case of netflix. On Research, Journal EU Business School, 4, 8-13.

Rouke, L. (2004). Validity in content analyisis. Educational Technology Research and Development, 52(1), 5-18.

Sarı, U., \& Sancaklı, P. (2020). Küyerelleşmenin dijital platformların içerik tanıtımına etkisi: Netflix örneği. Erciyes İletişim Dergisi, 7(1), 243-260. doi:10.17680/ erciyesiletisim. 647463

Segado, F., Grandío, M.-d.-M., \& Fernández-Gómez, E. (2015). Social media and television: a bibliographic review based on the Web of Science. El Profesional De La Información, 24(3), 227-234. doi:10.3145/epi.2015.may.02

Tankovska, H. (2021, 21 Ocak). Number of Monthly Active Twitter Users Worldwide from 1st Quarter 2010 to 1st quarter 2019. Statista.com.Erişim adresi: https://www. statista.com/statistics/282087/number-of-monthly-active-twitter-users/

Thomas, Z. (2020, 21 Nisan). Netflix Gets 16 million New Sign-ups Thanks to lockdown. bbc.com. Erişim adresi: https://www.bbc.com/news/business-52376022

Van Es, K. (2016). Social TV and the participation dilemma in NBC's The Voice. Television \& New Media, 17(2), 108-123. doi:10.1177/1527476415616191

Digital Around the World In April 2020 (2020, 23 Nisan). We Are Social. Erişim adresi: https://wearesocial.com/blog/2020/04/digital-around-the-world-in-april-2020 


\title{
Video On Demand Platforms' Twitter Use as A Marketing Communication Strategy: A Research on Netflix Turkey During the Pre and Post Covid-19 Period
}

\author{
Dilek Melike Uluçay (Asst. Prof. Dr.) \\ Güven Zararsız (Part Time Lect.) \\ Umut Can Aytekin (MA Student)
}

\section{Extended Abstract}

As media technologies have evolved, the way viewers consume and interact with media has also changed. The time and place-dependent content offered by traditional broadcasting to the audience has turned into content that the viewers can share with anyone anywhere, regardless of time and place. Particularly subscription-based "video on demand" platforms enable the consumption of rich content that viewers can access 24/7 via mobile technologies (Paz Perez, 2020). At the same time, these demandoriented platforms have changed their monitoring practices. New audience habits, such as watching more than one episode of a series at the same time, have led the industry to offer new technical equipment and services to meet the audience's needs. For example, Netflix, which is considered to be the pioneer of "on demand" televisions, can add the "skip the opening" tab, allowing viewers to skip the intro without playing the content forward (Paz Perez, 2020, p. 8).

New televisions have affected not only the habits of viewers to consume content, but also the habits of viewers to share content. Social media, in particular, has accelerated the sharing of the content and the interaction of the viewers with the broadcasting platforms. Accordingly, "video on demand" platforms have started to use social media marketing intensively in their marketing strategies (Gómez \& Quevedo, 2018).

Netflix, according to an official announcement given in September 2019, with its 167 million paid users in 190 different countries around the world, is the world leader in "video on demand" (VOD) sector. Additionally, it has over 1.7 million users in Turkey ("Netflix Türkiye Abone"). The company, which is the pioneer and leader of the sector, has an approach that uses social media marketing communication strategies extensively and looks at the audience interaction as part of the service it offers. It is observed that the company is trying to mobilize its audience and influence monitoring practices, especially in Twitter (Van Es, 2016).

In addition to all these, there was an increase of 16 million in the number of Netflix users as a result of home quarantines due to the pandemic in the first quarter of 2020. According to the statements of company officials, this increase is almost twice of the last months of 2019 (Thomas, 2020). With the global coronavirus epidemic process, it has been announced that the total number of subscribers of the platform has reached 203.7 million ("Netflix Güncel Abone") It is thought that the platform may have made changes or innovations in both traditional marketing communication strategies and social media usage strategies.

Twitter is one of the most frequently incorporated social media platforms in network marketing strategies and plays a central role in second screen marketing (Segado, 
Grandío, \& Fernández-Gómez, 2015). One of the reasons for this is that, according to 2019 data, Twitter has 330 million followers worldwide and is one of the social media platforms that enable the most interaction (Tankovska, 2021).

The aim of this study is to investigate how Netflix Turkey uses Twitter as a marketing communication tool. Another aim of the study is to reveal whether the use of Twitter of Netflix Turkey has changed its strategies with the COVID-19 pandemic process. For this purpose, quantitative content analysis was used in the study. Quantitative content analysis means grouping communication content into items, associating each item with a category, and determining a numerical value for each category (Rouke, 2004).

According to the results of the study, the total number of tweets shared on Netflix Türkiye account between the dates 11 January 2020 and 11 May 2020 is 228. 36,84\% of the tweets were shared before the first official announcement of COVID case in Turkey, and the rest $(63,16 \%)$ shared after the announcement of the first case. The most important reason for this is thought to be that people spend time at home with the quarantine decision and their content viewing habits increase. However, the company used Twitter to promote content intensively in both periods. However, the most used plugin by the company is the use of hashtags for both periods. It was observed that there were differences in time periods of sharing as a result of the changes in the hours spent at home due to the pandemic.

The continuation of pandemic conditions, the ongoing process of home quarantines, and the imposition of restrictions on different areas of life, undoubtedly led to significant changes in consumer behavior. The increase in the time spent at home, the rise in screen time, the transfer of entertainment concept from outside to inside will lead to the diversification and rise of other VOD platforms such as Netflix. Increasing demand and the changing consumer behavior will lead these channels to use new marketing communication approaches. On the other hand, while the pandemic conditions continue, the changes in all areas of life will undoubtedly continue to be the subject of research in marketing communication, consumer behavior, behavioral sciences and innovative approaches.

Keywords: Communication, Social Media, Video on Demand (VOD), Twitter, Quantitative Content Analysis.

Bu makale intihal tespit yazılımlarıyla taranmıştır. Intihal tespit edilmemiştir.

This article has been scanned by plagiarism detection softwares. No plagiarism detected.

Bu çalışmada "Yükseköğretim Kurumları Bilimsel Araştırma ve Yayın Etiği Yönergesi” kapsamında uyulması belirtilen kurallara uyulmuştur.

In this study, the rules stated in the "Higher Education Institutions Scientific Research and Publication Ethics Directive" were followed.

Yazarların çalışmadaki katkı oranları; birinci yazar \%40, ikinci yazar \%30, üçüncü yazar \%30.

Contribution rates of the authors in the study; first author $40 \%$, second author $30 \%$, third author $30 \%$.

Çalışma kapsamında herhangi bir kurum veya kişi ile çıkar çatışması bulunmamaktadır.

There is no conflict of interest with any institution or person within the scope of the study. 